\title{
Hubungan Merokok dan Pendidikan terhadap Fungsi Kognitif Civitas Akademika di Lingkungan Universitas Muhammadiyah Jakarta
}

\author{
Risky Akaputra ${ }^{1}$, RR. Hestin Diah Prasanty ${ }^{2}$ \\ ${ }^{1,2}$ Program Studi Kedokteran Fakultas Kedokteran dan Kesehatan Universitas Muhammadiyah Jakarta \\ Jl. KH. Ahmad Dahlan, Ciputat, Cirendeu, Banten 15419 \\ Email: artupaka@gmail.com
}

\begin{abstract}
ABSTRAK
Perilaku merokok masih merupakan masalah kesehatan dunia karena dapat menyebabkan berbagai penyakit dan bahkan kematian. Salah satu kandungan rokok yaitu nikotin memiliki efek terhadap otak antara lain menyebabkan ketergantungan dan toksisitas pada fungsi kognitif. Tujuan penelitian ini untuk mengetahui hubungan merokok (derajat merokok dan ketergantungan nikotin) dan pendidikan terhadap fungsi kognitif di lingkungan Universitas Muhammadiyah Jakarta. Penelitian ini merupakan penelitian dengan desain studi cross sectional yang menggunakan kuesioner baku brinkman, fagerstorm dan Montreal Cognitive Assessment versi Indonesia (MoCA-Ina). Pengambilan sampel dilakukan dengan cara consecutive sampling dimana subjek yang sesuai dengan kriteria inklusi dimasukkan sampai jumlah yang diperlukan terpenuhi, jumlah sampel pada penelitian ini berjumlah 96 responden. Kriteria inklusi dalam penelitian ini adalah orang yang berusia 18-50 tahun dan memiliki kebiasaan merokok. Berdasarkan hasil uji Chi Square diketahui terdapat hubungan yang signifikan antara derajat merokok $(\mathrm{p}=0.024)$, ketergantungan nikotin $(\mathrm{p}=0.021)$, dan pendidikan $(\mathrm{p}=0.014)$ terhadap fungsi kognitif.
\end{abstract}

Kata kunci: merokok, pendidikan, fungsi kognitif

\section{Correlation of Smoking and Education towards Civitas Academica Cognitive Function in University of Muhammadiyah Jakarta}

\begin{abstract}
Smoking still as world health problem because it can cause various diseases and even death. One of the content of cigarettes that nicotine has effects on the brain, among others, cause dependence and toxicity in cognitive function. The purpose of this research is to know the relationship of smoking (degree of smoking, depth of suction, nicotine dependency) and education to cognitive function in Muhammadiyah University of Jakarta. This research is a cross sectional study using standard brinkman, fagerstorm and Montreal Cognitive Assessment Indonesia (MoCA-Ina) questionnaire. Sampling was done by consecutive sampling where subjects according to the inclusion criteria were included until the required amounts were met, the number of samples in this study amounted to 96 respondents. The inclusion criteria in this study were people aged 1850 years and had a smoking habit. Based on Chi Square test results, there was a significant
\end{abstract}


correlation between smoking degree $(\mathrm{p}=0.024)$, depth of suction $(\mathrm{p}=0.019)$, nicotine dependence $(\mathrm{p}=0.021)$, and education $(\mathrm{p}=0.014)$ to cognitive function.

Keywords: smoking, education, cognitive function

Latar Belakang

Perilaku merokok masih merupakan masalah kesehatan dunia karena dapat menyebabkan berbagai penyakit dan bahkan kematian ${ }^{1}$. Menurut The Tobacco Atlas $3^{\text {rd }}$ edition, terkait presentase penduduk dunia yang mengkonsumsi tembakau didapatkan sebanyak $57 \%$ pada penduduk Asia dan Australia, pada penduduk Eropa Timur 14\%, penduduk Amerika 12\%, penduduk Eropa Barat 9\%, dan $8 \%$ pada penduduk Timur Tengah dan Afrika. Pada kawasan Asia Tenggara dengan $10 \%$ dari seluruh perokok dunia dan $20 \%$ penyebab kematian global akibat tembakau. Persentase perokok pada penduduk di Negara ASEAN tersebar di Indonesia 46.16\%, Filipina 16.62\%, Vietnam $14.11 \%$, Myanmar $8.73 \%$, Thailand 7.74\%, Malaysia 2.90\%, Kamboja $2.07 \%$, Laos $1.23 \%$, Singapura $0.39 \%$, dan Brunei $0.04 \%{ }^{2}$.

Menurut Kementerian Kesehatan Republik Indonesia, sekitar $65.9 \%$ laki-laki dan $4.2 \%$ perempuan di atas umur 15 tahun merokok. Usia konsumsi rokok paling rendah terjadi pada kelompok umur 15-24 tahun dan kelompok umur 75 tahun ke atas ${ }^{3}$. Perilaku merokok di Indonesia khususnya remaja telah menjadi masalah yang memerlukan penanganan serius karena prevalensi yang semakin meningkat dan usia mulai merokok semakin muda, yaitu 7 tahun pada remaja laki-laki. ${ }^{1} \mathrm{Hal}$ ini berarti kebanyakan perokok adalah generasi muda atau usia produktif ${ }^{3}$. Data pada Lembaga Demografi Fakultas Ekonomi Universitas Indonesia tahun 2006 mencatat bahwa "rokok merupakan pengeluaran terbesar kedua yaitu sebesar $11.89 \%$ setelah pengeluaran untuk padi-padian yang mencapai $22.10 \%$, dan lebih tinggi dari pengeluaran untuk biaya listrik, telepon dan bahan bakar minyak (BBM) yang sebesar $10.95 \%$ dan kontrak tempat tinggal yang mencapai $8.82 \% " 1$.

Haustein dan Groneberg menyatakan merokok tidak hanya berpengaruh pada kesehatan fisik semata. Kebiasaan menghisap tembakau bertahun tahun berpengaruh terhadap kesehatan fungsi otak dan psikis. Salah satu kandungan rokok yaitu nikotin, memiliki efek terhadap otak antara lain menyebabkan ketergantungan dan toksisitas pada fungsi kognitif. Efek ketergantungan inilah yang mengakibatkan paparan terus menerus pada perokok nantinya akan mengakibatkan penurunan fungsi kognitif bagi usia pelajar. Penurunan fungsi kognitif akan berdampak pada proses pembelajaran dan perolehan nilai akhir ${ }^{4}$.

Murray menyatakan bahwa nikotin dapat memberikan efek positif pada 
Risky Akaputra dan RR. Hestin Diah Prasanty, Hubungan Merokok dan Pendidikan terhadap Fungsi Kognitif Civitas Akademika di Lingkungan Universitas Muhammadiyah Jakarta DOI : $10.24853 /$ jkk.14.1.48-55

pengguna rokok tersebut. Fungsi nikotin dapat membantu dalam atensi (perhatian), proses belajar dan memori. Pada sistem kolinergik, terdapat reseptor asetilkolin nikotinik yang dapat berikatan dengan nikotin. Penggunaan nikotin sebagai agonis, menyebabkan peningkatan fungsi dari reseptor asetilkolin nikotinik, seperti peningkatan memori, atensi dan proses pembelajaran. Peningkatan fungsi ini hanya berlangsung singkat apabila konsumsi dihentikan, sehingga pengguna mengkonsumsi rokok kembali untuk mendapatkan efek peningkatan tersebut. Efek peningkatan yang terjadi secara terusmenerus ini diperkirakan akan menyebabkan reseptor asetilkolin nikotinik menjadi kelelahan dan menurun bersamaan dengan usia ${ }^{5}$. Berbanding terbalik dengan hasil penelitian Anstey yang menyatakan bahwa merokok dalam jangka panjang dapat mempercepat penurunan fungsi kognitif dan juga merupakan faktor risiko untuk menimbulkan kelainan fungsi kognitif, salah satunya demensia ${ }^{6}$.

Menurut Elsawati, fungsi kognitif adalah suatu kejadian yang mampu mengembangkan pikiranya melalui pengalaman - pengalaman yang dialami dan mampu melatih ingatanya melalui peristiwa eksperimen atau percobaan yang didapatkan. Kognitif juga memiliki ciri-ciri yaitu berpikir lancar, berpikir luwes, berpikir orisinal, dan berpikir terperinci ${ }^{7}$.
Pada penelitian yang dilakukan di Mexico terhadap lansia menunjukkan adanya hubungan yang jelas antara penurunan fungsi kognitif dan variabelvariabel termasuk di dalamnya umur, pendidikan, status pernikahan, komposisi anggota keluarga dan beberapa kondisi medis seperti stroke, diabetes mellitus dan riwayat merokok ${ }^{11}$. Hasil penelitian menyebutkan sekitar lebih dari setengah total sampel mengalami gangguan fungsi kognitif, di mana umur, faktor pendidikan dan faktor merokok berpengaruh pada fungsi kognitif ${ }^{8}$ Penelitian ini bertujuan untuk mengetahui hubungan antara merokok (derajat merokok dan ketergantungan nikotin) serta pendidikan dengan fungsi kognitif di lingkungan Universitas Muhammadiyah Jakarta.

\section{Metode Penelitian}

Desain penelitian ini adalah studi cross sectional untuk menggambarkan dan menilai hubungan merokok (berupa derajat merokok, dan ketergantungan nikotin) serta pendidikan dengan fungsi kognitif di lingkungan Universitas Muhammadiyah Jakarta. Penelitian ini dilakukan pada bulan Desember tahun 2016 di lingkungan Universitas Muhammadiyah Jakarta. Populasi pada penelitian ini adalah civitas akademika yang berada di sekitar lingkungan Universitas Muhammadiyah Jakarta. Sampel dari penelitian ini adalah civitas akademika yang berada di 
lingkungan Universitas Muhammadiyah Jakarta berjumlah 96 yang memenuhi kriteria inklusi. Pengambilan sampel dilakukan dengan cara consecutive sampling dimana subjek yang sesuai dengan kriteria inklusi dimasukkan sampai jumlah yang diperlukan terpenuhi. Kriteria inklusi dalam penelitian ini adalah orang yang berusia 18 50 tahun dan memiliki kebiasaan merokok, sedangkan kriteria ekslusinya adalah orang yang memiliki riwayat trauma kepala dan stroke ringan atau TIA (Transient Ischemic Attack).

Jenis data yang digunakan untuk penelitian ini adalah data primer, terdiri dari: nama, usia, pendidikan, pekerjaan, status perkawinan, jumlah rokok per hari, usia pertama kali merokok. Data didapat dari responden dengan kuesioner baku brinkman (untuk derajar merokok), fagerstorm (untuk ketergantungan nikotin) dan tes fungsi kognitif dengan menggunakan Montreal Cognitive Assessment versi Indonesia (MoCA-Ina). Data dianalisis menggunakan SPSS 17 dengan hasil analisis univariat dan analisis bivariat.

\section{Hasil}

Hasil uji analisis univariat pada penelitian ini menunjukkan jumlah perokok paling banyak ada pada masa remaja akhir yaitu usia 18-25 tahun, dan jumlah perokok paling sedikit pada usia masa dewasa awal, yaitu usia 26-35 tahun. Variabel derajat merokok dikelompokan menjadi 3, yaitu derajat merokok ringan, derajat merokok sedang, dan derajat merokok berat. Berdasarkan hasil penelitian yang di dapat, jumlah terbanyak ada pada perokok dengan derajat merokok sedang, yaitu 43 orang dengan persentase $44.8 \%$.

Pendidikan pada penelitian ini terbagi menjadi SD, SMP, SMA, dan STRATA 1. Hasil analisis menunjukkan sebagian besar responden berpendidikan SMP yaitu sebanyak 41 orang dengan persentase $42.7 \%$. Fungsi kognitif pada perokok di bagi menjadi 2, yaitu perokok dengan gangguan kognitif dan perokok yang tidak mengalami gangguan kognitif atau normal. Berdasarkan penelitian yang di dapat, jumlah terbanyak ada pada perokok dengan gangguan kognitif dibandingkan dengan fungsi kognitif yang normal, yaitu 80 orang dengan presentase $83.3 \%$. Dari tabel 6 didapatkan bahwa fungsi kognitif pada responden dengan tidak mengalami gangguan kognitif berjumlah 16 orang dengan persentase $16.7 \%$. Tabel 2 merupakan hasil analisis bivariat mengenai hubungan merokok dan pendidikan dengan fungsi kognitif. Hasil analisis tersebut menunjukkan bahwa merokok yang terdiri dari derjat merokok dan ketergantungan nikotin serta pendidikan memiliki hubungan yang signifikan dengan fungsi kognitif. Hal ini dibuktikan dengan nilai $p$ value pada derjat merokok, ketergantungan nikotin dan pendidikan kurang dari $0.05(\mathrm{p}<0.05)$. 
Risky Akaputra dan RR. Hestin Diah Prasanty, Hubungan Merokok dan Pendidikan terhadap Fungsi Kognitif Civitas Akademika di Lingkungan Universitas Muhammadiyah Jakarta DOI : $10.24853 /$ jkk.14.1.48-55

Tabel 1. Distribusi berdasarkan Usia, Pendidikan, Derajat Merokok, Ketergantungan Nikotin dan Fungsi Kognitif Responden

\begin{tabular}{llll}
\hline & Variabel & Frekuensi & Persen (\%) \\
\hline Usia & &
\end{tabular}

18-25 tahun

26-35 tahun

36-50 tahun

\section{Derajat Merokok}

$\begin{array}{lll}\text { Ringan } & 11 & 11.5 \\ \text { Sedang } & 43 & 44.8 \\ \text { Berat } & 42 & 43.8\end{array}$

\section{Ketergantungan Nikotin}

Ketergantungan Sangat Ringan

Ketergantungan Ringan

Ketergantungan Sedang

Ketergantungan Berat

Ketergantungan Sangat

Berat

\section{Pendidikan}

$\begin{array}{lcc}\text { SD } & 12 & 12.5 \\ \text { SMP } & 41 & 42.7 \\ \text { SMA } & 40 & 41.7 \\ \text { STRATA 1 } & 3 & 3.1 \\ & & \\ \text { Fungsi Kognitif } & & \\ \text { Gangguan Kognitif } & 80 & 83.3 \\ \text { Normal } & 16 & 16.7\end{array}$

\section{Pembahasan}

Hasil uji univariat pada tabel menunjukan kategori usia perokok di lingkungan Universitas Muhammadiyah Jakarta sebagian besar adalah usia 18-25 tahun, yaitu sebanyak 35 orang dengan persentase $36.5 \%$. Hal ini tidak sejalan dengan hasil riskesdas 2013 bahwa proporsi nasional terbanyak perokok aktif ada pada rentang umur 30-34 tahun ${ }^{9}$. Hal ini dikarenakan sebagian responden adalah mahasiswa sehingga umur responden yang didapatkan kurang bervariasi.

Berdasarkan hasil analisis dengan indeks brinkman, sebagian besar responden berada pada indeks brinkman sedang sebesar 44.8\%. Hasil analisis membuktikan bahwa derajat berat merokok berhubungan dengan fungsi kognitif dengan $\mathrm{p}=0.024(\mathrm{p}<0.05)$. Hal ini disebabkan karena kandungan nikotin yang terdapat dalam rokok dapat mempengaruhi fungsi kognitif pada seseorang. Semakin banyak mengkonsumsi rokok semakin sering reseptor asetilkolinergik nikotinik mengalami depolarisasi (desensitisasi) yang menyebabkan reseptor tersebut mengalami kelelahan. Hal ini menyebabkan perokok pada derajat merokok sedang dan berat lebih banyak mengalami gangguan fungsi kognitif ${ }^{10}$. Hal ini juga ditemukan pada penelitian Starr, Deary, Whalley, dan Fox dalam penelitiannya Smoking and cognitive change from age 11-66 years: a confirmatory investigation ${ }^{11}$ dan penelitian Stewart, Deary, Rowkes, dan Price yang berjudul Relationship between lifetime smoking, smoking status at older age and 
cognitive human cognitive function $2006^{8}$. Hasil penelitian tersebut sejalan dengan hasil penelitian bahwa ada hubungan antara perilaku merokok terhadap fungsi kognitif lansia ${ }^{12}$. Namun, penelitian ini tidak sejalan dengan penelitian Arina dan Marchadinda yang menyatakan bahwa tidak ada hubungan dan pengaruh antara kebiasaan merokok dengan fungsi kognitif $^{13,14}$. Penelitian lain, juga menyatakan bahwa tidak terdapat hubungan bermakna antara kebiasaan merokok dengan kecenderungan demensia atau penurunan fungsi kognitif $^{15}$.

Ketergantungan nikotin berdasarkan kuesioner fagerstrom didapatkan sebagian besar responden berada pada ketergantungan ringan sebanyak $32.3 \%$. Ketergantungan nikotin dengan fungsi kognitif menunjukkan hasil yang signifikan dengan $\mathrm{p}=0.021(\mathrm{p}<0.05)$. Hasil penelitian ini sejalan dengan penelitian Haustein dan Groneberg bahwa salah satu kandungan rokok yaitu nikotin, memiliki efek pada otak antara lain menyebabkan ketergantungan dan toksisitas pada fungsi kognitif yang memunculkan gejala kesulitan konsentrasi ${ }^{16}$. Efek ketergantungan nikotin inilah yang mengakibatkan paparan terus menerus rokok pada perokok nantinya akan mengakibatkan penurunan fungsi kognitif bagi usia pelajar. Penurunan fungsi kognitif akan berdampak pada proses pembelajaran dan nilai akhir ${ }^{5}$.

Tabel 2. Hubungan Merokok dan Pendidikan dengan Fungsi Kognitif

\begin{tabular}{|c|c|c|c|c|c|}
\hline \multirow{3}{*}{ Variabel } & \multicolumn{4}{|c|}{ Fungsi Kognitif } & \multirow{3}{*}{$P$ value } \\
\hline & \multicolumn{2}{|c|}{ Normal } & \multicolumn{2}{|c|}{$\begin{array}{c}\text { Gangguan } \\
\text { Kognitif }\end{array}$} & \\
\hline & $\mathbf{n}$ & $\%$ & $\mathbf{n}$ & $\%$ & \\
\hline \multicolumn{6}{|l|}{ Derajat Merokok } \\
\hline Ringan & 5 & 45.5 & 6 & 54.5 & $0.024 *$ \\
\hline Sedang & 6 & 14.0 & 37 & 86.0 & \\
\hline Berat & 5 & 11.9 & 37 & 88.1 & \\
\hline \multicolumn{6}{|l|}{ Ketergantungan } \\
\hline \multicolumn{6}{|l|}{ Nikotin } \\
\hline Sangat Ringan & 6 & 50.0 & 6 & 50.0 & $0.021 *$ \\
\hline Ringan & 3 & 9.7 & 28 & 90.3 & \\
\hline Sedang & 3 & 17.6 & 14 & 82.4 & \\
\hline Berat & 2 & 12.5 & 14 & 87.5 & \\
\hline Sangat Berat & 2 & 10.0 & 18 & 90.0 & \\
\hline \multicolumn{6}{|l|}{ Pendidikan } \\
\hline SD & 1 & 8.3 & 11 & 91.7 & $0.014 *$ \\
\hline SMP & 3 & 7.3 & 38 & 92.7 & \\
\hline SMA & 10 & 25.0 & 30 & 75.0 & \\
\hline S1 & 2 & 66.7 & 1 & 33.3 & \\
\hline
\end{tabular}


Risky Akaputra dan RR. Hestin Diah Prasanty, Hubungan Merokok dan Pendidikan terhadap Fungsi Kognitif Civitas Akademika di Lingkungan Universitas Muhammadiyah Jakarta DOI : $10.24853 /$ jkk.14.1.48-55

Pendidikan dalam penelitian ini terdiri dari SD, SMP, SMA dan S1. Hasil univariat menunjukan bahwa pendidikan responden dengan jumlah terbanyak ada pada responden dengan pendidikan SMP yaitu $42.7 \%$, dan responden dengan persentase pendidikan terkecil yaitu pada STRATA 1 (S1) sebanyak 3.1\%. Hubungan antara pendidikan terhadap fungsi kognitif merupakan hubungan yang bermakna dan signifikan dengan $\mathrm{p}=0.014(\mathrm{p}<0.05)$. Hasil penelitian ini sejalan dengan penelitian Gusti Ayu, Nyoman Ratep, dan Wayan Westa ${ }^{17}$ dan juga penelitian Setiawan ${ }^{18}$ yang berpendapat bahwa responden dengan pendidikan yang rendah lebih banyak mengalami gangguan pada fungsi kognitif dibandingkan dengan responden dengan pendidikan yang tinggi

\section{Kesimpulan dan Saran}

Berdasarkan hasil penelitian ini dapat diambil kesimpulan bahwa terdapat hubungan yang signifikan antara derajat merokok, ketergantungan nikotin dan pendidikan dengan fungsi kognitif. Hasil penelitian ini dapat menjadi salah satu bahan promosi kesehatan mengenai edukasi bahaya merokok. Selain itu, perlu dilakukan penelitian lebih dalam mengenai faktorfaktor lain dan besar pengaruh variabel terhadap penurunan fungsi kognitif.

\section{Daftar Pustaka}

1. Chotidjah S. Pengetahuan Tentang
Rokok, Pusat Kendali Kesehatan Eksternal dan Perilaku Merokok. Makara Sos Hum. 2012;16(1):4956.

2. Sahfey O, Eriksen M, Ross $\mathrm{H}$, Mackay J. The Tobacco Atlas Third Edition. 2002;30-3.

3. Pusat Promosi Kesehatan. Pedoman Pengembangan Kawasan Tanpa Rokok. Pus Promosi Kesehatan, Kementeri Kesehat Republik Indones [Internet]. 2011; Available from:

http://www.depkes.go.id/resources/d ownload/promosi-

kesehatan/pedoman-ktr.pdf

4. Haustein KO, Groneberg D. Tobacco or Health? 2009.

5. Murray KN, Abeles N. Nicotine's Effect on Neural and Cognitive Functioning in an Aging Population. Aging Ment Heal [Internet]. 2002;6(2):129-38. Available from: https://www.ncbi.nlm.nih.gov/pubm ed/12028881

6. Anstey KJ, Von Sanden C, Salim A, O'Kearney R. Smoking as a risk factor for dementia and cognitive decline: A meta-analysis of prospective studies. Am J Epidemiol. 2007;166(4):367-78.

7. Elsawati. Analisis Pengembangan Kemampuan Kognitif pada Anak Kelompok B di Tk Negeri Pembina Ki Hajar Dewantoro Kecamatan 
Kota Selatan Kota Gorontalo. 2014.

8. Stewart M, Deary I, Fowkes F, Prices

J. Relationship between Lifetime Smoking, Smoking Status at Older Age and Human Cognitive Function. Neuroepidemiology [Internet]. 2006;26(2):83-92. Available from: https://www.ncbi.nlm.nih.gov/pubm ed/16352911

9. Badan Penelitian dan Pengembangan Kesehatan Republik Indonesia. Riset Kesehatan Dasar (RISKESDAS) 2013. Badan Penelitian dan Pengembangan Kesehatan Kementerian Kesehatan RI. 2013.

10. Benowitz N. Clinical Pharmacology of Nicotine: Implications for Understanding, Preventing, and Treating Tobacco Addiction. Nat Publ Art [Internet]. 2008;83(4):53141. Available from: https://www.ncbi.nlm.nih.gov/pubm ed/18305452

11. Starr JM, Deary IJ, Fox HC, Whalley LJ. Smoking and cognitive change from age 11 to 66 years: a confirmatory investigation. Addict Behav. 2006;32(1).

12. Husniyah L, Purwaningsih $\mathrm{H}$, Widodo GG. Hubungan Perilaku Merokok Terhadap Fungsi Kognitif Lansia di Kelurahan Gedanganak Kecamatan Ungaran Timur Kabupaten Semarang. 2015;

13. Triasti AP, Pudjonarko D. Faktor -
Faktor Yang Mempengaruhi Fungsi Kognitif Penderita Stroke Non Hemoragik. J Kedokt Diponegoro. 2016;5(4):460-74.

14. Suprapto MI. Hubungan Riwayat Merokok dengan Gangguan Kognitif pada Pasien Stroke. 2014.

15. Fernanda F, Husein AN, Bakhriansyah M. Hubungan Merokok dengan Kecenderungan Demensia pada Laki Laki Lanjut Usia di Kecamatan Banjarmasin Barat Periode Juni-September 2013. Berk Kedokt. 2014;10(2).

16. Haustein KO, Groneberg D. Tobacco or Health? 2nd Edition. Berlin: Springer; 2010.

17. Sundariyati IAH, Ratep N, Westa W. Gambaran Faktor-Faktor yang Mempengaruhi Status Kognitif pada Lansia di Wilayah Kerja Puskesmas Kubu II, Januari-Februari 2014. EJurnal Med Udayana. 2015;4(1).

18. Setiawan DI, Bidjuni H, Karundeng M. Hubungan Tingkat Pendidikan dengan Kejadian Demensia pada Lansia di Balai Penyantunan Lanjut Usia Senja Cerah Paniki Kecamatan Mapanget Manado. J Keperawatan. 2014;2(2):1-7. 